\title{
Profesyonel Futbolcularda Sporda İnsan Hakları Tutumu ve Özgünlük Düzeylerinin İncelenmesi
}

\author{
Mehmet Behzat TURAN ${ }^{1}$ \\ Oğulcan USUFLU ${ }^{1}$ \\ Kenan KOÇ ${ }^{1}$ \\ Barış KARAOĞLU ${ }^{1}$ \\ Hakkı ULUCAN ${ }^{1}$
}

${ }^{1}$ Erciyes Üniversitesi Spor Bilimleri Fakültesi, KAYSERI

Künye: Turan, M.B., Usuflu, O., Koç, K., Karaoğlu, B. ve Ulucan, H. (2018). Profesyonel Futbolcularda Sporda İnsan Hakları Tutumu ve Özgünlük Düzeylerinin İncelenmesi. Gaziantep Üniversitesi Spor Bilimleri Dergisi, 3(4): 1-18.

\section{Öz}

$\mathrm{Bu}$ araştırmanın amacı profesyonel olarak futbol oynayan sporcuların sporda insan hakları tutumu ve özgünlük düzeylerinin incelenmesidir. Araştırmaya Türkiye Futbol Federasyonu bünyesinde bulunan profesyonel olarak kabul edilen; Süper Lig, 1. Lig, 2.Lig ve 3. Lig takımlarında aktif olarak futbol oynayan 1912 futbolcudan rastgele seçilmiş 674 futbolcu çalışmanın örneklemini oluşturmaktadır. Futbolculara araştırmacı tarafından oluşturulan sosyo demografik bilgi formu, Akın ve Dönmezoğulları (2010) tarafından geçerliliği güvenirliği yapılmış Özgünlük ölçeği ve Sadık (2014) tarafından geçerliliği ve güvenirliliği yapılmış, Sporda İnsan Hakları Tutumu ölçeği uygulanmıştır. Elde edilen verilerin dağılımları için Kolmogrov Smirnov test istatistiği kullanılmış ve istatistiki analizler için parametrik testler kullanılmıştır. Adaylara ilişkin kişisel bilgiler, ölçek toplam puanları ile frekans (f) ve yüzde (\%) değerleri tespit edilerek verilmiştir. Ölçeklerden elde edilen puanlar arasındaki farklıı̆̆ı ortaya koyabilmek için yaş, spor yaşı, oynadığı lig, oynandığı mevki ve eğitim durumlarına göre karşılaştırmalarda One Way Anova testi kullanılmıştır. Farklıı̆ın kaynağını tespit edebilmek için de Post Hoc testlerinden LSD istatistiğinden faydalanılmıştır. Araştırmada elde edilen sonuçlara göre futbolcuların Sporda insan hakları tutumu ve Özgünlük düzeylerinin yaş, spor yaşı, oynadığı lig ve eğitim durumuna göre farklılaştığı tespit edilmiştir. Dünya da olduğu gibi aynı zamanda Ülkemizde de popüler bir meslek olan futbolculuğun toplum tarafından göz önünde bulunduğu ve bunların bakış açıların toplumu yönlendirdiği bilinmektedir. Elde edilen sonuçların toplumla ilişkilendirilerek, insanların sporda insan hakları tutumlarının ve özgünlüklerinin artırabileceği ve herkes için olan sporun toplum da daha fazla yer alabileceği düşünülmektedir.

Anahtar Kelimeler: İnsan Hakları, Futbol, Özgünlük

\section{Orijinal Makale}

Yayın Bilgileri

Gönderi Tarihi: 11.05.2018

Kabul Tarihi: 20.11.2018

Yayın Tarihi: 28.12.2018

Sorumlu Yazar

e-mail: justified13@hotmail.com

DOI: $10.31680 /$ gaunjss.422883

\section{Analysis of Uniqueness Levels and Attitudes about Human Rights Among Professional Football (Soccer) Athletes}

\begin{abstract}
The purpose of this research was to examine the level of human rights attitudes in sports and authenticity of professional football (soccer) athletes. The research participants were all considered professionals by the Turkey Football Federation. They belonged to the Super League, 1st League, 2nd League or 3rd League teams. 1912 were randomly selected from 674 players actively playing. This researcher created a socio-demographic information form, the authenticity scale, which was validated by Akın and Dönmezoğulları (2012). The players also filled out the Human Rights Attitude in Sports Scale, validated by Sadık (2014). The Kolmogorov-Smirnov test statistic was used for the distribution of obtained data and parametric tests were used for statistical analysis. Personal information about the candidates was determined by the scale total scores and frequency (f) and percent (\%) values. The one-way ANOVA test was used to compare the scores obtained from the scales according to age, sports age, league, position, and educational status. The LSD statistic was used in post-hoc tests to determine the source of differences. The results showed that the football players' attitudes towards human rights and their level of authenticity differed according to age, sports age, league and educational attainment.

Football, or soccer, a popular occupation in Turkey and throughout the world, is considered by the society and these aspects lead the society. It is believed that the results are indicative of general societal attitudes, that people's attitudes and beliefs about human rights can be improved, and that the sports society for everyone can take more place.
\end{abstract}

\section{Original Article}

Article Info

Received: 11.05 .2018

Accepted: 20.11 .2018

Published: 28.12.2018

Corresponding Author e-mail: justified13@hotmail.com 


\section{Giriş}

İnsan hakları kavramının doğal hukukun bir parçası olduğu kabul edilmektedir. Buna göre insan, insan olmak sıfatıyla, yapısı gereği, vazgeçilmez, devredilmez, zamanaşımına uğramaz haklara sahiptir. Bir insanın bu haklara sahip olması, belirli bir işi yapmasına, belirli bir rolü icra etmesine veya belli görevleri yapmasına bağlı değildir, bu haklar insan olmasından dolayı sadece ona aittir (Coşkun, 2006). Günümüzde insan hakları ve temel özgürlüklerin tanınması, evrensel bir ilgi odağı olmakla kalmamış, bunların güvence altına alınarak aykırı gidişlerden korunması ve daha ileri düzeyle gerçekleştirilmesi amacıyla birçok uluslararası kuruluşlar oluşturulmuş ve bu kuruluşlar aracılığıyla çeşitli sözleşmeler yapılmıştır. Bu kuruluşların başında, hemen hemen tüm dünya ülkelerini kapsayan Birleşmiş Milletler örgütü gelmektedir.

Birleşmiş Milletler Bildirgesinde sosyal güvenlik, çalışma, sağlık, eğitim gibi temel hak ve özgürlükler yer almaktadır. Sosyal devlet anlayışı çerçevesinde söz konusu hakların yerine getirilmesi gerekmektedir. Böylece, sosyal devlette, herkesin sağlıklı ve dengeli bir çevrede yaşama hakkı, herkesin hayatını, ruh ve beden sağlığı içinde sürdürme hakkı, sağlık koşullarına uygun meskenlerde oturma hakkı, gelecek ve yoksulluk korkularından kurtulma hakkı vardır (Göze, 2005). Doğrudan bildirgelerde yer almamasına rağmen başka bir hak daha vardır bu da spor hakkıdır. Toplum içinde edindiği yer, bireylerin zihinsel, fiziksel, ruh bakımından yetkinleşmesine yaptığı etkilerden, dünya barışı ve kardeşliğine sunmuş olduğu katkılardan dolayı spor da temel insan hakları içinde sayılabilir (Sadık, 2014).

Günümüzde insanların fiziksel, zihinsel ve toplumsal bakımdan gelişimi grup çalışmasının kolaylaştıııması, karşılıklı dayanışmanın sağlanması ve toplum üyeliğinin kazanılmasının en kolay yollarından biri spor olgusudur. Sporun insanın kişiliği üzerine olan etkileri göz önünde bulundurulduğunda, ne derece önemli olduğu ortaya çıkmaktadır. Bu yönü ile sporun, bireyin kendi dar dünyasından kurtularak başka ortamlarda, başka düşüncelerden insanlarla diyalog içinde bulunmasını, onlardan etkilenmesini ve onları etkilemesini sağlayarak insanların gelişiminde önemli bir yeri vardır. Spor ortamlarında ortaya çıkan yaşantılar gerçek yaşamın küçük bir parçası olarak düşünülebilir. Dolayısıyla spor; üstlenmiş olduğu huzur, barış, kardeşlik ve dostluk gibi önemli değerleri ortaya çıkaran bir olgu olarak değerlendirilmektedir (Sadık, 2014). 
Spor branşlarına bakıldığında ise gerek etkileşim gerekse kitleleri etkilemesi açısından futbol son derece etkili bir spor daldır. Öte yandan 2024 yılında yapılacak olan Avrupa futbol şampiyonasına ev sahipliği yapacak aday ülkelerdeki insan haklarının durumuna önem verileceğinin açıklanması da futbol ve insan hakları kavramlarının ilişkisinin incelenmesi konusunu dikkat çekici hale getirmiştir. $\mathrm{Bu}$ bağlamda futbolcuların gerek hak ve özgürlükler konusundaki tutumlarının, gerekse futbolculara sağlanan ve sağlanması gereken haklara ilişkin bakış açısının saptanmasının önemli olduğu düşünülmektedir. Durum bu şekildeyken futbolcuların insan haklarına bakışının ne olduğu ve ne kadar özgün olabildikleri sorusu akla gelmektedir.

Özgünlük, sağlıktan insan gelişimine, danışma psikolojisinden kişilik ile ilgili önemli teorilere kadar pek çok alanda anahtar bir kavram olarak ele alınmıştır (Lopez ve Rice, 2006). Kernis ve Goldman'a (2006) göre özgünlük, bireyin günlük yaşamını hiç engellenmeksizin gerçek veya özbenliğine göre sürdürebilmesidir. Böylece kişi, diğer insanların duygu düşünce ve değer yargılarının etkisinde kalmadan kendine has bir şekilde yaşayabilir. Bu tür bir yaşamda harekete geçmeye, kişinin kendi duyguları değerleri ve yorumlamaları liderlik etmektedir (Sağlam, 2012). Özgünlük bireyin düşünce ve davranışlarına yönelik derinlemesine farkındalığa sahip olması şeklinde ele alınmıştır (Avolio ve Gardner, 2005). Bireyin düşünce ve davranışlarına yönelik farkındalığının yanı sıra, değerler açısından da özgünlüğü işlevsel olması gerekmektedir. $\mathrm{Bu}$ bağlamda bireylerin değerlerini keşfetmeleri önemlidir. Özgünlüğün önemli bir işlevi olarak; bireylerin içsel dinamiklerini tanıyıp, değerlerini de netleştirerek ikisi arasında tutarlılık da özgünlügün önemli bir işlevi olarak görülmüştür (Raths ve ark., 1978).

Tüm bu kaynaklar ve tanımlamalar incelendiğinde futbolcuların tutum ve davranışlarını inceleyen çalışmalar yapılmasına intiyaç olduğu ve alan yazında bu tür çalışma sayısının yetersiz olduğu düşünülmektedir. Bu noktadan hareketle çalışmamızın amacı futbolcuların insan hakları tutumu ve özgünlük düzeylerini bazı değişkenler açısından incelemektir. Böylece futbolcular yetiştirilirken özellikle erken yaşlarda tedbirler alınıp yönlendirmeler yapılabilir ve çalışmamız daha sonra yapılacak olanlara rehberlik edebilir. 


\section{Yöntem}

\section{Araştırmanın Modeli}

Bu araştırma betimsel ve ilişkisel tarama modelindedir. Bu tarama modelleri, “...iki ve daha çok sayıdaki değişken arasında birlikte değişim varlığını ve/veya derecesini belirlemeyi amaçlayan araştırma modelleri" şeklinde tanımlanabilir (Karasar, 2007). Araştırmaya Türkiye Futbol Federasyonu bünyesinde bulunan profesyonel olarak kabul edilen; Süper Lig, 1. Lig, 2.Lig ve 3. Lig takımlarında aktif olarak futbol oynayan futbolcuların insan hakları ve özgünlük tutumları ile bazı demografik özellikleri arasındaki ilişkiler konularında durum tespiti yapılacağından dolayı betimsel nitelik taşımaktadır.

\section{Evren ve Örneklem}

Süper Lig, 1. Lig, 2.Lig ve 3. Lig takımlarında aktif olarak futbol oynayan, 1912 futbolcudan rastgele seçilmiş 674 futbolcu çalışmanın örneklemini oluşturmaktadır.

\section{Veri Toplama Araçları}

Araştırmada kullanılan veri toplama araçları; Sporda insan hakları tutum ölçeği, Özgünlük ölçeği ve sosyo demografik bilgi formu uygulanmıştır.

\section{Sporda İnsan Hakları Tutum Ölçeği}

Sadık (2014) tarafından geliştirilen ve sporcunun insan hakları tutum profilini ortaya çıkaran 'Sporda İnsan Hakları Tutum Ölçeği' kullanılmıştır. 5'li likert tipi kapalı uçlu sorularla hazırlanan 29 soruluk envanterin cevap seçenekleri "Tamamen Katılıyorum (5), Katılıyorum (4), Kararsızım (3), Katılmıyorum (2), Hiç Katılmıyorum (1)" seklindedir Ölçek geliştirme çalışmalarında güvenirlik katsayısı Cronbach Aıpha iç tutarlılık katsayısı hesaplanmaktadır. Ölçek faktörlerinin güvenirlik katsayıları kişilik hakları boyutunda .88, sosyal haklar boyutunda .79, dayanışma hakları boyutunda .83 olarak hesaplanmıştır. Ölçek güvenirliği ise .82 bulunmuştur. Bu değerler ölçek güvenirliği için yeterli düzeydedir (Sadık, 2014).

\section{Özgünlük Ölçeği}

Bireylerin özgünlük yapısındaki kişilerarası farklılıkları değerlendirmek amacıyla Wood ve ark., (2008) tarafından geliştirilen Özgünlük Ölçeği, 12 maddeden ve öz-yabancılaşma (4 madde, örneğin; "içimdeki duygularımın tam olarak farkında 
değilim"), dışsal etkiyi kabul etme (4 madde, örneğin; "diğer insanların düşüncelerinden önemli ölçüde etkilenirim") ve özgün yaşam (4 madde, örneğin; "inandığım şeylerin her zaman arkasında dururum") şeklinde 3 alt ölçekten oluşmaktadır. 7'li Likert tipi bir derecelendirmeye sahip olan ölçeğin Türkçeye uyarlama çalışması Akın ve Dönmezoğluları (2010) tarafından yapıımıştır. Özgünlük Ölçeğinin faktör yükleri .60 ile .83 arasında değişmektedir. Ölçeğin iç tutarlıık katsayıları öz yabancılaşma için .73 , dışsal etkiyi kabul etme için .72 ve özgün yaşam için .75 olarak bulunmuştur (Akın ve Dönmezoğulları, 2010).

\section{Sosyo-Demografik Bilgi Formu}

Sosyo demografik bilgi formu, katıımcıların yaş, spor yaşı, oynadığı lig, oynadığı mevki, eğitim durumu bilgilerini elde etmek amacıyla 5 soru içermektedir.

\section{Sınırlılıklar}

- Çalışmaya amatör liglerdeki futbolcularda dâhil edilirse kapsam geçerliği daha yüksek olacaktır.

- Sporda insan hakları envanteri farklı branşlara da uygulanıp branşlar arası karşılaştırılmalarda da kullanılırsa daha geniş bir açıyla spor ve insan hakları tutumu ele alınmış olur.

- Daha küçük yaşlarda insan hakları tutumu ölçülüşeydi geliştirici çalışmalar yapılabilirdi.

\section{Verilerin Analizi}

Futbolculara araştırmacı tarafından oluşturulan sosyo demografik bilgi formu, Akın ve Dönmezoğulları (2010) tarafından geçerliliği güvenirliği yapılmış Özgünlük ölçeği ve Sadık (2014) tarafından geçerliliği ve güvenirliliği yapılmış, Sporda İnsan Hakları Tutumu ölçeği uygulanmıştır. Elde edilen verilerin dağılımları için Kolmogrov Smirnov test istatistiği kullanılmış ve istatistiki analizler için parametrik testler kullanılmıştır. Adaylara ilişkin kişisel bilgiler, ölçek toplam puanları ile frekans (f) ve yüzde (\%) değerleri tespit edilerek verilmiştir. Ölçeklerden elde edilen puanlar arasındaki farklılı̆ı ortaya koyabilmek için yaş, spor yaşı, oynadığı lig, oynandığı mevki ve eğitim durumlarına göre karşılaştırmalarda One Way Anova testi kullanılmıştır. Farklıı̆ın kaynağını tespit edebilmek için de Post Hoc testlerinden LSD istatistiğinden faydalanılmıştır. 
Tablo 1: Demografik Özellikler

\begin{tabular}{cccc}
\hline & Değişkenler & $\mathbf{N}$ & $\%$ \\
\hline \multirow{4}{*}{ Yaş } & $18-20$ & 133 & 19.7 \\
& $21-25$ & 288 & 42.7 \\
& $26-30$ & 191 & 28.3 \\
& $31-35$ & 62 & 9.2 \\
\hline \multirow{5}{*}{ Spor Yaşı } & $1-5$ & 81 & 12.0 \\
& $6-10$ & 262 & 38.9 \\
& $11-15$ & 217 & 32.2 \\
& $16-20$ & 69 & 10.2 \\
& $21+$ & 45 & 6.7 \\
\hline \multirow{3}{*}{ Oynadığı Lig } & Süper Lig & 78 & 11.6 \\
& 1. Ligg & 108 & 16.0 \\
& 2. Lig & 118 & 17.5 \\
& 3. Lig & 370 & 54.9 \\
\hline \multirow{3}{*}{ Oynadığı Mevki } & Kaleci & 90 & 13.4 \\
& Defans & 232 & 34.4 \\
& Orta Saha & 243 & 36.1 \\
& Forvet & 109 & 16.2 \\
\hline \multirow{2}{*}{ Eğitim Durumu } & Ilköğretim & 20 & 3.0 \\
& Ortaöğretim & 393 & 38.3 \\
& Lisans & 261 & 38.7 \\
\hline
\end{tabular}

\section{Bulgular}

Tablo 2: Ölçeklerden Elde Edilen Puanların Betimsel İstatistiği

\begin{tabular}{cccccc}
\hline & Alt Boyutlar & $\mathbf{n}$ & Min & Max & X \\
& Kişilik Hakları & 674 & 37.00 & 60.00 & $51.09 \pm 4.42$ \\
\hline \multirow{2}{*}{$\begin{array}{c}\text { Insan } \\
\text { Hakları }\end{array}$ Tutumu } & Sosyal Haklar & 674 & 13.00 & 45.00 & $31.77 \pm 6.29$ \\
\cline { 2 - 6 } & Dayanışma Hakları & 674 & 14.00 & 40.00 & $31.97 \pm 4.24$ \\
\cline { 2 - 6 } & İnsan Hakları Total & 674 & 78.00 & 145.00 & $114.83 \pm 10.81$ \\
\hline \multirow{3}{*}{ Özgünleşme } & Öz Yabancılaşma & 674 & 4.00 & 28.00 & $13.56 \pm 6.05$ \\
\cline { 2 - 6 } & Dışsal Etkiyi Kabul Etme & 674 & 4.00 & 28.00 & $14.49 \pm 5.56$ \\
\cline { 2 - 6 } & Özgünleşme & 674 & 4.00 & 28.00 & $22.16 \pm 5.30$ \\
\hline
\end{tabular}

Tablo 2 incelendiğinde kişilik hakları ortalamasının 51,09, sosyal haklar ortalamasının 31,77 dayanışma hakları ortalamasının 31,97 ve toplam insan hakları puan ortalamalarının 114,83 olarak tespit edildiği görülmektedir. Öte yandan öz yabancılaşma ortalaması 13,56 dışsal etkiyi kabul etme ortalaması 14,49 iken özgünleşme toplam puan ortalaması 22,16 olarak hesaplanmıştır. 
Tablo 3: Sporcuların Sporda İnsan Hakları Tutumları ve Özgünlük Düzeylerinin Yaşa Göre Karşılaştırılması

\begin{tabular}{|c|c|c|c|c|c|c|}
\hline & Yaş & $\mathrm{N}$ & $\mathrm{X} \pm \mathrm{SS}$ & $f$ & $p$ & LSD \\
\hline \multirow{5}{*}{ Kişilik Hakları } & $16-20^{\mathrm{a}}$ & 133 & $51,29 \pm 4,69$ & \multirow{5}{*}{,432 } & \multirow{5}{*}{,786 } & \multirow{5}{*}{ - } \\
\hline & $21-25^{b}$ & 288 & $50,85 \pm 4,44$ & & & \\
\hline & $26-30^{c}$ & 191 & $51,34 \pm 4,27$ & & & \\
\hline & $31-35^{d}$ & 62 & $51,00 \pm 4,23$ & & & \\
\hline & Total & 674 & $51,09 \pm 4,42$ & & & \\
\hline \multirow{5}{*}{ Sosyal Haklar } & $16-20^{a}$ & 133 & $33,52 \pm 6,58$ & \multirow{5}{*}{4,959} & \multirow{5}{*}{,001 } & $a-b$ \\
\hline & $21-25^{b}$ & 288 & $31,61 \pm 6,26$ & & & $a-c$ \\
\hline & $26-30^{C}$ & 191 & $31,20 \pm 6,14$ & & & $a-d$ \\
\hline & $31-35^{d}$ & 62 & $29,71 \pm 5,19$ & & & \\
\hline & Total & 674 & $31,77 \pm 6,29$ & & & \\
\hline \multirow{5}{*}{$\begin{array}{c}\text { Dayanışma } \\
\text { Hakları }\end{array}$} & $16-20^{a}$ & 133 & $31,95 \pm 4,27$ & \multirow{5}{*}{,927 } & \multirow{5}{*}{,448 } & \multirow{5}{*}{ - } \\
\hline & $21-25^{b}$ & 288 & $31,88 \pm 4,41$ & & & \\
\hline & $26-30^{C}$ & 191 & $32,23 \pm 3,96$ & & & \\
\hline & $31-35^{d}$ & 62 & $31,33 \pm 4,17$ & & & \\
\hline & Total & 674 & $31,97 \pm 4,24$ & & & \\
\hline \multirow{5}{*}{$\begin{array}{c}\text { Öz } \\
\text { Yabancılaşma }\end{array}$} & $16-20^{a}$ & 133 & $13,50 \pm 6,43$ & \multirow{5}{*}{ 137 } & \multirow{5}{*}{,969 } & \\
\hline & $21-25^{b}$ & 288 & $13,52 \pm 5,90$ & & & \\
\hline & $26-30^{c}$ & 191 & $13,73 \pm 6,23$ & & & \\
\hline & $31-35^{d}$ & 62 & $13,46 \pm 5,59$ & & & \\
\hline & Total & 674 & $13,56 \pm 6,05$ & & & \\
\hline \multirow{5}{*}{$\begin{array}{l}\text { Dışsal Etkiyi } \\
\text { Kabul Etme }\end{array}$} & $16-20^{a}$ & 133 & $15,26 \pm 6,06$ & \multirow{5}{*}{1,448} & \multirow{5}{*}{,216 } & \multirow{5}{*}{ - } \\
\hline & $21-25^{b}$ & 288 & $14,48 \pm 5,29$ & & & \\
\hline & $26-30^{c}$ & 191 & $14,36 \pm 5,56$ & & & \\
\hline & $31-35^{d}$ & 62 & $13,52 \pm 5,54$ & & & \\
\hline & Total & 674 & $14,49 \pm 5,56$ & & & \\
\hline \multirow{5}{*}{ Özgünleşme } & $16-20^{a}$ & 133 & $22,65 \pm 4,91$ & \multirow{5}{*}{,867 } & \multirow{5}{*}{,484 } & \multirow{5}{*}{ - } \\
\hline & $21-25^{b}$ & 288 & $21,81 \pm 5,54$ & & & \\
\hline & $26-30^{c}$ & 191 & $22,39 \pm 5,23$ & & & \\
\hline & $31-35^{d}$ & 62 & $21,79 \pm 5,27$ & & & \\
\hline & Total & 674 & $22,16 \pm 5,30$ & & & \\
\hline
\end{tabular}

Tablo 3 incelendiğinde kişilik hakları alt boyutu açısından hiçbir yaş grubu arasında anlamlı farklıık bulunmazken ortalamaların birbirine yakın olduğu görülmektedir. Sosyal haklar alt boyutu açısından 16/20 yaşlar ile $21 / 25$, 26/30 ve 31/35 yaşalar arasında anlamlı farklılıklar tespit edilirken $36+$ yaş grubu ile $31 / 35$ yaş grubu arasında da anlamlı düzeyde fark olduğu hesaplanmıştır. Dayanışma hakları alt boyutunda da herhangi bir yaş grubu arasında anlamlı farklılık tespit edilememiştir. Özgünleşme açısından bakıldığında; alt boyutlarda ve özgünleşme toplamında yaş grupları arasında anlamlı farklııılar görülmemektedir. 
Tablo 4: Sporcuların Sporda İnsan Hakları Tutumları ve Özgünlük Düzeylerinin Spor Yaşına Göre Karşılaştırılması

\begin{tabular}{|c|c|c|c|c|c|c|}
\hline & Spor Yaşı & $\mathrm{n}$ & $\mathrm{X} \pm \mathrm{SS}$ & $f$ & $\mathrm{p}$ & LSD \\
\hline \multirow{6}{*}{ Kişilik Hakları } & $1-5^{a}$ & 81 & $50,01 \pm 4,41$ & \multirow{6}{*}{2,203} & \multirow{6}{*}{,067 } & \multirow{6}{*}{ - } \\
\hline & $6-10^{b}$ & 262 & $50,99 \pm 4,41$ & & & \\
\hline & $11-15^{c}$ & 217 & $51,66 \pm 4,40$ & & & \\
\hline & $16-20^{\mathrm{d}}$ & 69 & $51,13 \pm 4,34$ & & & \\
\hline & 21 ve üzeri & 45 & $50,80 \pm 4,47$ & & & \\
\hline & Total & 674 & $51,09 \pm 4,42$ & & & \\
\hline \multirow{6}{*}{ Sosyal Haklar } & $1-5^{a}$ & 81 & $32,26 \pm 5,42$ & \multirow{6}{*}{4,270} & \multirow{6}{*}{,002* } & \multirow{6}{*}{$\begin{array}{l}b-c \\
b-d \\
b-e\end{array}$} \\
\hline & $6-10^{b}$ & 262 & $32,86 \pm 6,01$ & & & \\
\hline & $11-15^{c}$ & 217 & $30,88 \pm 6,78$ & & & \\
\hline & $16-20^{\mathrm{d}}$ & 69 & $30,54 \pm 6,10$ & & & \\
\hline & 21 ve üzeri ${ }^{\mathrm{e}}$ & 45 & $30,64 \pm 6,20$ & & & \\
\hline & Total & 674 & $31,77 \pm 6,29$ & & & \\
\hline \multirow{6}{*}{$\begin{array}{l}\text { Dayanışma } \\
\text { Hakları }\end{array}$} & $1-5^{a}$ & 81 & $31,60 \pm 4,06$ & \multirow{6}{*}{,549 } & \multirow{6}{*}{,700 } & \multirow{6}{*}{ - } \\
\hline & $6-10^{b}$ & 262 & $32,16 \pm 4,18$ & & & \\
\hline & $11-15^{c}$ & 217 & $31,99 \pm 4,24$ & & & \\
\hline & $16-20^{\mathrm{d}}$ & 69 & $32,06 \pm 4,08$ & & & \\
\hline & 21 ve üzeri ${ }^{e}$ & 45 & $31,33 \pm 5,09$ & & & \\
\hline & Total & 674 & $31,97 \pm 4,24$ & & & \\
\hline \multirow{6}{*}{ Öz Yabancılaşma } & $1-5^{a}$ & 81 & $13,21 \pm 5,68$ & \multirow{6}{*}{ 946 } & \multirow{6}{*}{ 436 } & \multirow{6}{*}{ - } \\
\hline & $6-10^{b}$ & 262 & $13,86 \pm 5,98$ & & & \\
\hline & $11-15^{c}$ & 217 & $13,75 \pm 6,23$ & & & \\
\hline & $16-20^{\mathrm{d}}$ & 69 & $12,39 \pm 5,58$ & & & \\
\hline & 21 ve üzeri ${ }^{\mathrm{e}}$ & 45 & $13,29 \pm 6,81$ & & & \\
\hline & Total & 674 & $13,56 \pm 6,05$ & & & \\
\hline \multirow{6}{*}{$\begin{array}{l}\text { Dışsal Etkiyi Kabul } \\
\text { Etme }\end{array}$} & $1-5^{a}$ & 81 & $14,68 \pm 5,41$ & \multirow{6}{*}{2,765} & \multirow{6}{*}{ 102 } & \multirow{6}{*}{ - } \\
\hline & $6-10^{b}$ & 262 & $14,97 \pm 5,23$ & & & \\
\hline & $11-15^{c}$ & 217 & $14,27 \pm 5,79$ & & & \\
\hline & $16-20^{\mathrm{d}}$ & 69 & $14,64 \pm 5,44$ & & & \\
\hline & 21 ve üzeri ${ }^{e}$ & 45 & $15,02 \pm 6,26$ & & & \\
\hline & Total & 674 & $14,49 \pm 5,56$ & & & \\
\hline \multirow{6}{*}{ Özgünleşme } & $1-5^{a}$ & 81 & $22,17 \pm 4,72$ & \multirow{6}{*}{1,621} & \multirow{6}{*}{,167 } & \multirow{6}{*}{ - } \\
\hline & $6-10^{b}$ & 262 & $21,74 \pm 5,32$ & & & \\
\hline & $11-15^{c}$ & 217 & $22,64 \pm 5,30$ & & & \\
\hline & $16-20^{d}$ & 69 & $21.51 \pm 5.81$ & & & \\
\hline & 21 ve üzeri ${ }^{\mathrm{e}}$ & 45 & $23,29 \pm 5,15$ & & & \\
\hline & Total & 674 & $22,16 \pm 5,30$ & & & \\
\hline
\end{tabular}

Tablo 4 incelendiğinde spor yaşı değişkeniyle kişilik hakları ve dayanışma hakları arasında yaş grupları açısından anlamlı farklılıklar tespit edilmemiştir. Sosyal haklar açısından bakıldığında ise $6 / 10$ yıl ile $11 / 15,26 / 20$ ve $20+$ yılları arasında anlamlı farklııklar olduğu hesap edilmiştir. Diğer taraftan özgünleşmenin alt boyutları açısından yaş grupları arasında anlamlı farklııklar tespit edilmemiştir. 
Tablo 5: Sporcuların Sporda İnsan Hakları Tutumları ve Özgünlük Düzeylerinin Mevkilere Göre Karşılaştırıması

\begin{tabular}{|c|c|c|c|c|c|c|}
\hline & Mevki & $\mathbf{n}$ & X土SS & $f$ & $\mathbf{p}$ & LSD \\
\hline \multirow{5}{*}{ Kişilik Hakları } & Kaleci $^{\mathrm{a}}$ & 90 & $51,49 \pm 4,43$ & \multirow{5}{*}{,393 } & \multirow{5}{*}{,758 } & \multirow{5}{*}{-} \\
\hline & Defans $^{b}$ & 232 & $50,90 \pm 4,31$ & & & \\
\hline & $\begin{array}{l}\text { Orta } \\
\text { Saha }^{c}\end{array}$ & 243 & $51,13 \pm 4,56$ & & & \\
\hline & Forvet $^{d}$ & 109 & $51,06 \pm 4,37$ & & & \\
\hline & Total & 674 & $51,09 \pm 4,42$ & & & \\
\hline \multirow{5}{*}{ Sosyal Haklar } & Kaleci $^{\mathrm{a}}$ & 90 & $31,83 \pm 6,09$ & \multirow{5}{*}{, 165} & \multirow{5}{*}{,920 } & \multirow{5}{*}{-} \\
\hline & Defans $^{b}$ & 232 & $31,58 \pm 6,63$ & & & \\
\hline & $\begin{array}{l}\text { Orta } \\
\text { Saha }^{c}\end{array}$ & 243 & $31,78 \pm 6,06$ & & & \\
\hline & Forvet $^{d}$ & 109 & $32,08 \pm 6,27$ & & & \\
\hline & Total & 674 & $31,77 \pm 6,29$ & & & \\
\hline \multirow{5}{*}{ Dayanışma Hakları } & Kaleci $^{\mathrm{a}}$ & 90 & $32,22 \pm 3,86$ & \multirow{5}{*}{1,150} & \multirow{5}{*}{,328 } & \multirow{5}{*}{-} \\
\hline & Defans $^{b}$ & 232 & $32,24 \pm 3,86$ & & & \\
\hline & $\begin{array}{c}\text { Orta } \\
\text { Saha }^{c}\end{array}$ & 243 & $31,58 \pm 4,70$ & & & \\
\hline & Forvet $^{\mathrm{d}}$ & 109 & $32,08 \pm 4,21$ & & & \\
\hline & Total & 674 & $31,97 \pm 4,24$ & & & \\
\hline \multirow{5}{*}{ Öz Yabancılaşma } & Kaleci $^{\mathrm{a}}$ & 90 & $13,49 \pm 5,98$ & \multirow{5}{*}{,339 } & \multirow{5}{*}{,797 } & \multirow{5}{*}{-} \\
\hline & Defans $^{b}$ & 232 & $13,61 \pm 5,97$ & & & \\
\hline & $\begin{array}{c}\text { Orta } \\
\text { Saha }^{\mathrm{c}}\end{array}$ & 243 & $13,33 \pm 6,20$ & & & \\
\hline & Forvet $^{d}$ & 109 & $14,02 \pm 5,97$ & & & \\
\hline & Total & 674 & $13,56 \pm 6,05$ & & & \\
\hline \multirow{5}{*}{$\begin{array}{c}\text { Dışsal Etkiyi Kabul } \\
\text { Etme }\end{array}$} & Kaleci $^{\mathrm{a}}$ & 90 & $14,09 \pm 5,56$ & \multirow{5}{*}{, 533} & \multirow{5}{*}{,660 } & \multirow{5}{*}{ - } \\
\hline & Defans $^{b}$ & 232 & $14,39 \pm 5,61$ & & & \\
\hline & $\begin{array}{l}\text { Orta } \\
\text { Saha }^{\mathrm{c}}\end{array}$ & 243 & $14,49 \pm 5,46$ & & & \\
\hline & Forvet $^{\mathrm{d}}$ & 109 & $15,04 \pm 5,69$ & & & \\
\hline & Total & 674 & $14,49 \pm 5,56$ & & & \\
\hline \multirow{5}{*}{ Özgünleşme } & Kaleci $^{\mathrm{a}}$ & 90 & $22,34 \pm 5,18$ & \multirow{5}{*}{,383 } & \multirow{5}{*}{,765 } & \multirow{5}{*}{-} \\
\hline & Defans $^{b}$ & 232 & $22,39 \pm 5,41$ & & & \\
\hline & $\begin{array}{l}\text { Orta } \\
\text { Saha }^{\mathrm{c}}\end{array}$ & 243 & $22,04 \pm 5,41$ & & & \\
\hline & Forvet $^{\mathrm{d}}$ & 109 & $21,81 \pm 4,94$ & & & \\
\hline & Total & 674 & $22,16 \pm 5,30$ & & & \\
\hline
\end{tabular}

Futbolcuların oynadıkları mevkiler ile insan hakları ve özgünlük alt boyutları arasında hiçbir değişkende anlamlı bir farklılığa rastlanmamıştır. 
Tablo 6: Sporcuların Sporda İnsan Hakları Tutumları ve Özgünlük Düzeylerinin Oynadıkları Lige Göre Karşılaştıııması

\begin{tabular}{|c|c|c|c|c|c|c|}
\hline & & $\mathbf{n}$ & $\mathrm{X} \pm \mathrm{SS}$ & $f$ & $p$ & LSD \\
\hline \multirow{5}{*}{ Kişilik Hakları } & Süper Liga & 78 & $49,28 \pm 2,32$ & \multirow{5}{*}{11,342} & \multirow{5}{*}{, $000^{*}$} & \multirow{5}{*}{$\begin{array}{l}a-c \\
a-d \\
b-c \\
b-d\end{array}$} \\
\hline & $1 . \mathrm{Llg}^{\mathrm{b}}$ & 108 & $49,73 \pm 4,37$ & & & \\
\hline & 2. Lig $^{\mathrm{C}}$ & 118 & $51,96 \pm 4,28$ & & & \\
\hline & 3. Lig $^{\mathrm{d}}$ & 370 & $51,59 \pm 4,63$ & & & \\
\hline & Total & 674 & $51,09 \pm 4,42$ & & & \\
\hline \multirow{5}{*}{ Sosyal Haklar } & Süper Lig ${ }^{a}$ & 78 & $29,53 \pm 3,83$ & \multirow{5}{*}{10,960} & \multirow{5}{*}{, $000^{*}$} & \multirow{5}{*}{$\begin{array}{c}a-b \\
a-c \\
a-d \\
b-c / b-d\end{array}$} \\
\hline & 1.Lig & 108 & $33,93 \pm 4,94$ & & & \\
\hline & 2. Lig $^{\mathrm{C}}$ & 118 & $33,13 \pm 6,44$ & & & \\
\hline & 3. ig $^{\mathrm{d}}$ & 370 & $31,17 \pm 6,74$ & & & \\
\hline & Total & 674 & $31,77 \pm 6,29$ & & & \\
\hline \multirow{5}{*}{ Dayanışma Hakları } & Süper Liga & 78 & $32,04 \pm 2,97$ & \multirow{5}{*}{1,851} & \multirow{5}{*}{ 137 } & \\
\hline & 1.LIg ${ }^{\mathrm{b}}$ & 108 & $31,92 \pm 3,83$ & & & \\
\hline & 2. Lig $^{\mathrm{C}}$ & 118 & $32,77 \pm 3,60$ & & & \\
\hline & 3.Lig ${ }^{\mathrm{d}}$ & 370 & $31,72 \pm 4,72$ & & & \\
\hline & Total & 674 & $31,97 \pm 4,24$ & & & \\
\hline \multirow{5}{*}{ Öz Yabancılaşma } & Süper Lig $^{\mathrm{a}}$ & 78 & $10,01 \pm 2,57$ & \multirow{5}{*}{14,217} & \multirow{5}{*}{, $000^{*}$} & \multirow{5}{*}{$\begin{array}{c}\text { a/b-c-d } \\
b / a-d \\
c / a-d \\
d / a-b-c\end{array}$} \\
\hline & 1. $\mathrm{Lig}^{\mathrm{b}}$ & 108 & $15,12 \pm 5,91$ & & & \\
\hline & 2. Lig $^{\mathrm{c}}$ & 118 & $14,92 \pm 6,24$ & & & \\
\hline & 3. igg $^{\mathrm{d}}$ & 370 & $13,41 \pm 6,23$ & & & \\
\hline & Total & 674 & $13,56 \pm 6,05$ & & & \\
\hline \multirow{5}{*}{$\begin{array}{c}\text { Dışsal Etkiyi Kabul } \\
\text { Etme }\end{array}$} & Süper Lig $^{\mathrm{a}}$ & 78 & $11,03 \pm 3,12$ & \multirow{5}{*}{15,113} & \multirow{5}{*}{, $000^{*}$} & \multirow{5}{*}{$\begin{array}{c}a / b-c-d \\
b-a \\
c / a-d \\
d / a-c\end{array}$} \\
\hline & 1.Lig ${ }^{b}$ & 108 & $14,92 \pm 5,60$ & & & \\
\hline & 2. Lig $^{\mathrm{c}}$ & 118 & $16,24 \pm 5,79$ & & & \\
\hline & 3. Lig $^{\mathrm{d}}$ & 370 & $14,54 \pm 5,57$ & & & \\
\hline & Total & 674 & $14,49 \pm 5,56$ & & & \\
\hline \multirow{5}{*}{ Özgünleşme } & Süper Lig $^{a}$ & 78 & $24,09 \pm 2,49$ & & \multirow{5}{*}{, $000^{*}$} & \multirow{5}{*}{$\begin{array}{c}a / b-d \\
b / a-c-d \\
c / b \\
d / a-b\end{array}$} \\
\hline & 1. $\mathrm{Lig}^{\mathrm{b}}$ & 108 & $20,45 \pm 5,36$ & \multirow{4}{*}{8,018} & & \\
\hline & 2. Lig $^{\mathrm{C}}$ & 118 & $22,78 \pm 4,96$ & & & \\
\hline & 3. Lig $^{\mathrm{d}}$ & 370 & $22,06 \pm 5,65$ & & & \\
\hline & Total & 674 & $22,16 \pm 5,30$ & & & \\
\hline
\end{tabular}

Tablo 6 incelendiğinde futbolcuların oynadıkları lig açısından kişilik hakları alt boyutunda süper lig ile 2. ve 3. Lig arasında, 1. lig ile de 2. ve 3. Lig arasında anlamlı farklıık tespit edilmiştir. Sosyal haklar açısından süper lig ile 1. 2. ve 3. Lig arasında ayrıca 1. lig ile 2. ve 3. Lig arasında anlamlı farklııklar hesaplanmıştır. Öte yandan öz yabancılaşma alt boyutunda ise süper lig ile 1. 2. ve 3. Lig arsında, 1.lig ile süper lig ve 3. lig arasında, 2. Lig ile süper lig ve 3. lig arasında, 3 3. lig ile süperlig,1. Lig ve 2. Lig arasında anlamlı farklııklar olduğu hesaplanmıştır. Dışsal etkiyi kabul etme açısından bakıldığında süper lig ile 1. 2. ve 3. Lig arsında, 1. lig ile süper lig arasında, , 2. Lig ile süper lig ve 3. lig arasında, 3.lig ile süper lig ve 2. Lig arasında anlamlı farklılıklar olduğu hesaplanmıştır. Özgünleşme alt boyutunda da süper lig ile 1.lig ve 3.lig arasında, 1.lig ile süper lig,2. Lig ve 3.lig arasında, 2. Lig ile 3. Lig arasında, 3.lig ile de süper lig ve 1. Lig arasında anlamlı farklılıklar olduğu görülmektedir. Diğer alt boyutlarda anlamlı bir farklıı̆̆a rastlanmamıştır 
Tablo 7: Sporcuların Sporda İnsan Hakları Tutumları ve Özgünlük Düzeylerinin Eğitim Durumlarına Göre Karşılaştırılması

\begin{tabular}{|c|c|c|c|c|c|c|}
\hline & Eğitim Kademesi & $n$ & $\mathrm{X} \pm \mathrm{SS}$ & $f$ & $p$ & LSD \\
\hline \multirow{4}{*}{ Kişilik Hakları } & ilkolkul $^{\mathrm{a}}$ & 20 & $50,45 \pm 4,56$ & \multirow{4}{*}{ 634 } & \multirow{4}{*}{,531 } & \\
\hline & Lise ve Dengi $^{\mathrm{b}}$ & 393 & $50,98 \pm 4,26$ & & & \\
\hline & Lisans $^{\mathrm{c}}$ & 261 & $51,30 \pm 4,65$ & & & \\
\hline & Total & 674 & $51,09 \pm 4,42$ & & & \\
\hline \multirow{4}{*}{ Sosyal Haklar } & İlkolkul & 20 & $30,85 \pm 5,36$ & \multirow{4}{*}{6,065} & \multirow{4}{*}{,002* } & \multirow{4}{*}{$b-c$} \\
\hline & Lise ve Dengi & 393 & $32,47 \pm 6,15$ & & & \\
\hline & Lisans & 261 & $30,77 \pm 6,43$ & & & \\
\hline & Total & 674 & $31,77 \pm 6,29$ & & & \\
\hline \multirow{4}{*}{$\begin{array}{l}\text { Dayanışma } \\
\text { Hakları }\end{array}$} & İlkolkul & 20 & $32,25 \pm 3,70$ & \multirow{4}{*}{ 083 } & \multirow{4}{*}{,921 } & \\
\hline & Lise ve Dengi & 393 & $32,00 \pm 4,12$ & & & \\
\hline & Lisans & 261 & $31,91 \pm 4,46$ & & & \\
\hline & Total & 674 & $31,97 \pm 4,24$ & & & \\
\hline \multirow{4}{*}{$\begin{array}{c}\text { Öz } \\
\text { Yabancılaşma }\end{array}$} & İlkolkul & 20 & $10,15 \pm 4,17$ & \multirow{4}{*}{3,813} & \multirow{4}{*}{,023* } & \multirow{4}{*}{$\begin{array}{c}a / b-c \\
b-a \\
c-a\end{array}$} \\
\hline & Lise ve Dengi & 393 & $13,86 \pm 6,08$ & & & \\
\hline & Lisans & 261 & $13,37 \pm 6,04$ & & & \\
\hline & Total & 674 & $13,56 \pm 6,05$ & & & \\
\hline \multirow{4}{*}{$\begin{array}{l}\text { Dışsal Etkiyi } \\
\text { Kabul Etme }\end{array}$} & İlkolkul & 20 & $10,50 \pm 4,99$ & \multirow{4}{*}{7,221} & \multirow{4}{*}{,001* } & \multirow{4}{*}{$\begin{array}{c}a / b-c \\
b-a \\
c-a\end{array}$} \\
\hline & Lise ve Dengi & 393 & $14,95 \pm 5,40$ & & & \\
\hline & Lisans & 261 & $14,11 \pm 5,69$ & & & \\
\hline & Total & 674 & $14,49 \pm 5,56$ & & & \\
\hline \multirow{4}{*}{ Özgünleşme } & İlkokul & 20 & $22,80 \pm 5,15$ & \multirow{4}{*}{1,378} & \multirow{4}{*}{ 253 } & \multirow{4}{*}{ - } \\
\hline & Lise ve Dengi & 393 & $21,88 \pm 5,15$ & & & \\
\hline & Lisans & 261 & $22,54 \pm 5,51$ & & & \\
\hline & Total & 674 & $22,16 \pm 5,30$ & & & \\
\hline
\end{tabular}

Tablo 7'e göre eğitim durumu değişkeni açısından bakıldığında sosyal haklar alt boyutunda lise ve dengi ile lisans mezunları arasında anlamlı farklılık olduğu tespit edilmiştir. Öz yabancılaşma alt boyutunda ilkokul ile lise ve lisans mezunları arasında, lise mezunları ile lisans mezunları arasında, lisans mezunları ile de ilkokul mezunları arasında anlamlı düzeyde farklııklar olduğu hesaplanmıştır. Dışsal etkiyi kabul etme alt boyutu açısından bakıldığında ise ilkokul ile lise ve lisans mezunları arasında, lise mezunları ile lisans mezunları arasında, lisans mezunları ile de ilkokul mezunları arasında anlamlı düzeyde farklılıklar olduğu hesaplanmıştır. Diğer alt boyutlarda anlamlı bir farklıı̆a rastlanmamıştır.

\section{Tartışma ve Sonuç}

Çalışmamızda futbolcuların yaş değişkenine göre insan hakları tutumu incelendiğinde kişilik ve dayanışma hakları alt boyutlarında anlamlı farklıı̆a rastlanmazken sosyal haklar açısından yaş artışına bağlı olarak anlamlı farklııklar tespit edilmiştir. Sosyal hak tutumlarında yaş ilerledikçe genel olarak azalma gözlenmektedir. Literatür tarandığı zaman konu ile ilgili bir çalışmaya 
rastlanmamaktadır ancak sağlıklı bir çevrede yaşamak; sağlıklı temiz içme ve kullanma suyuna erişmek; sağlıklı ve yeterli beslenebilmek, güvenli gıdaya ulaşabilmek; güvenli ve konforlu barınabilmek, kendi arzusu dışında ve stratejik, ekonomik ve kamusal gibi gerekçelerle yerinden, yurdundan edilmemek, göç etmek zorunda bırakılmamak, yaşamını kendi arzusuyla doğup büyüdüğü ortamda sürdürebilmek; ücretsiz, kaliteli ve güvenli sağlık hizmetlerine ulaşabilmek, en yüksek fiziksel ve zihinsel sağlık standardına sahip olabilmek; Eşit, adil, evrensel ve laik eğitimi özgür ve güvenli şekilde alabilmek; Güvenli, saygın ve sağlıklı koşullarda adil bir ücretle çalışmak, sendika üyesi olarak örgütlenebilmek; zorla çalıştırılmamak, insanca ve saygın yaşam koşullarında emekli olabilmek, çalışma dışında dinlenme zamanına sahip olabilmek, özgürce seyahat edebilmek, eğlenme faaliyetlerine zaman ve para ayırabilmek, evrensel ve yerel kültür ve sanata eşit ve ucuz imkanlarla ulaşabilmek anayasa ile koruma altına alınmış sosyal haklardır. Çalışmamızın sonuçlarını bu tanımlamayla karşılaştırdığımızda futbolcuların en üretken dönemlerine denk gelen bu yaş aralıklarında özgüven, fiziksel performans, kariyer, şöhret ve ekonomik açıdan iyi olmaya bağlı olarak; profesyonellik ve tecrübenin de yaşla beraber artması sonucu yaş ilerledikçe sosyal haklara ilginin azaldığı düşünülmektedir.

Futbolcuların spor yaşı değişkenine göre insan hakları tutumu incelendiğinde kişilik ve dayanışma hakları alt boyutlarında anlamlı farklılığa rastlanmazken sosyal haklar açısından yaş artışına bağlı olarak anlamlı farklılıklar tespit edilmiştir. Doğrudan insan hakları veya sosyal haklar ile futbol arasındaki ilişkiyi inceleyen bir çalışmama olmamasına rağmen; Sadık (2014) sporcuların insan hakları tutumuna yönelik yaptığı çalışmada takım ve bireysel sporlarda kişilik hakları alt boyutunda bireysel spor yapan sporcular lehine anlamlı fark bulunmuştur. Erşan ve arkadaşlarının (2009) yaptığı çalışmada takım sporu yapan bireylerin özgüveninin yüksek olduğu bulunmuştur. Tekin (2009) takım sporu ile uğrasan sporcuların sosyal zeka puanlarının bireysel sporlarla uğraşanlara göre düşük bulmuştur. Bilir (2014) tarafından sporculara yaptığı çalışmada temaslı sporlarla uğraşanların şiddete daha meyilli olduğunu tespit etmiştir. Koruç ve Bayar (1990) Takım sporları yapan kadınlar ile spor yapmayan kadınların karşılaştırılmasında takım sporları yapan kadınların daha enerjik, maceracı, risk almaya eğilimli, gereksiz kaygılardan uzak olduğu sonucuna ulaşmıştır. Bilge (1990) Takım sporcularının gösteriş ve saldırganlık gereksinimlerinin bireysel sporculardan daha fazla olduğunu tespit etmiştir. 
Çalışmamızda da spor yaşı bir anlamda tecrübe arttıkça futbolcuların sosyal haklara çok fazla dikkat etmediği görülmektedir. Futbolda takım sporu görüntüsü olsa da futbolcuların bireysel çalışma, kendi kariyerini düşünme ve kendi gelişimini birinci plana alma isteği vardır. Getirileri bakımından düşünülürse spor yaşı ilerledikçe kendi kazancını düşünmek normaldir çünkü spor yaşının artmasının profesyonelleşmeyi dolayısıyla ünlenmeyi ve parayı getireceğine inanılacağı buna bağlı olarak da sosyal haklar gibi toplumsal konuların ikinci plana atılacağı düşünülmektedir.

Futbolcuların oynadıkları mevkilere insan hakları ve özgünleşme düzeyleri incelendiğinde herhangi bir mevki ile değişkenler arasında anlamlı bir farklıı̆a rastlanmamıştır. Kırkcaldy (1982), bireysel ve takım sporlarıyla ilgili yaptığı araştırmada, takım sporlarının kişilik özelliklerinde anlamlı farklılıklar bulunması karşın, takım sporcularının kendi içindeki pozisyonlarda anlamı farklııklar bulamamıştır. Ince ve Şen (2006) yaptıkları çalışmada, Adana II'inde deplasmanlı ligde basketbol oynayan sporcuların problem çözme becerilerini incelemiş ancak anlamlı bir fark bulamamıştır. Gülşen (2008) değişik liglerde oynayan futbolcuların mevkilere göre problem çözme becerilerini incelemiş ama anlamlı farklıık bulamamıştır. Literatürdeki yapılan bu çalışmalar mevki ile futbolcuların çeşitli özellikleri arasında bizim çalışmamızda da olduğu gibi anlamlı bir fark tespit edememiştir. Bu yönüyle araştırmamız alan yazınla desteklenmektedir.

Futbolcuların oynadığı lig değişkenine göre insan hakları tutumu incelendiğinde kişilik hakları ve sosyal haklar alt boyutlarında anlamlı farklılıklar varken dayanışma hakları alt boyutunda herhangi bir farka rastlanmamıştır. Sadık (2014) çalışmasında takım ve bireysel sporlarda kişilik hakları alt boyutunda bireysel spor yapan sporcular lehine anlamlı fark bulunmuştur. Nia ve Besharat (2010) yaptıkları çalışmada, bireysel ve takım sporu yapan sporcuların kişilik özelliklerine bakılmıştır. Bireysel spor yapanların takım sporları yapanlara göre, daha sorumlu ve özerklikten daha yüksek puan aldıkları gözlenmiştir. Öte yandan Salar ve arkadaşlarının (2012) yaptığı "15-18 yas grubu takım ve ferdi spor yapan bireylerin duygusal durumlarının karşılaştırıması" isimli çalışmada, bireysel ve takım sporu yapan sporcuların duygusal özellikleri bakımından herhangi fark bulunamamıştır. Çon (2011)'un yaptığı, "Takım ve Ferdi Sporcuların Kişilik Özellikleriyle Sportif Performansları Arasındaki ilişkinin incelenmesi" çalışmasının sonuçlarına göre "kişiler arası özdeşim" bireysel sporcularda daha baskındır. Kaynaklardan da anlaşıldığı üzere literatürde konu ile alakalı farklı görüşler bulunmaktadır. Oynanan ligin 
profesyonelleşmesine paralel olarak sosyal ve kişilik haklarına karışı ilginin azaldığı görülmekte olup; bunun sebebinin süper lige doğru sadece başarıya motive olan sporcunun kariyerine yoğunlaşmasının ve hayatını profesyonelleşmeye endekslemesinin bir sonucu olduğu düşünülmektedir.

Futbolcuların oynadığı lig ile özgünleşme düzeyleri değişkeni incelendiğinde de tüm alt boyular arasında anlamlı farklılığın olduğu görülmektedir. Genel olarak lig seviyesi üst düzeye doğru çıktıkça dışsal etkiyi kabul etme ve öz yabancılaşma ortalama puanları düşerken, özgünleşme ortalama puanlarının arttığı görülmektedir. Erdoğan (2014) profesyonel futbolcularla yaptığı çalışma sonucunda; oynadıkları lig değişkeni açısından disiplin ve sorumluluk, güven ve bağışlama, dürüstlük ve paylaşım, saygı ve doğruluk, paylaşım ve saygı alt boyutlarında rastlanan sonuçların istatistiksel anlamda anlamlı olduğunu ve bu bulgulara paralel olarak da lig seviyesi arttıkça bireylerin bireysel anlamda değer düzeylerinde de bir artış olduğunu gözlemlemiştir. Adiloğulları (2011) çalışmasında futbolcuların aldığı yıllık ücreti yeterli bulanların, bulmayanlara göre takıma daha bağlı olduğunu ifade etmiştir. Olgun ve arkadaşları (2010) hemşireler üzerine yaptıkları bir araştırmada Öğrencilerin başarıı olmasını, öznel sorumluluk sahibi olmalarıyla ilişkilendirilmiştir. Bizde çalışmamızda üst liglerde oynayan futbolcuların daha özgün olduğu sonucuna varmış durumdayız. Üst liglerde oynayan futbolcuların rekabete ve kazanma isteğine bağıı olarak bireysel düşünmelerinin ve kendilerini daha orijinal hale getirmeye çalışmalarının özgünlüklerini arttırdığı düşünülmektedir.

Futbolcuların eğitim seviyesine göre bakıldığında sosyal haklar açısından lise mezunlarının lisans mezunlarından daha yüksek ortalamalara sahip olduğu ve aralarında istatistiksel açıdan anlamlı farklılıklar görüldüğü hesaplanmıştır. Literatürde bu konu ile ilgili yapılan bir çalışmaya rastlanmamıştır. Lise mezunu futbolcuların lisans eğitimi almadan meslek hayatına başlaması ve toplum içinde yer edinmeye erkenden başlaması, lisans öğrencilerinin yaşla birlikte anti sosyal bir yaşam tarzına geçme olasıı̆̆ının yüksekliği, lisans eğitimi sırasındaki mesleki yeterliliğe ulaştırma baskısı gibi sebeplerden kişisel çıkarların ön planda olması; lisans öğrencilerinin sosyal haklara bakışını olumsuz yönde etkilemiş olabileceği düşünülmektedir.

Futbolcuların eğitim seviyesine göre bakıldığında öz yabancılaşma ve dışsal etkiyi kabul etme alt boyutlarında anlamlı farklılıklar görülmektedir. Eğitim seviyesi artıkça dışsal etkiyi kabul etme ve öz yabancılaşma otalamalarının da arttığı 
görülmektedir. Eğitim seviyesinin artmasıyla kişinin eğitim sisteminde kalma süresi artmaktadır dolayısıyla antrenörün ve eğiticinin etkisi de artacak buda dışsal etkiyi artıracaktır. İletişim, etkileşim, güncellenme, bilişsel ve duyuşsal gelişim gibi olumlu özellikleri arttırmak için kendi başımıza olmaktan çok dışsal etkileri kabul etmemiz pozitif yönde etki edebilir. Abakay (2010) yılında profesyonel ve amatör futbolcular üzerinde yapmış olduğu çalışmada hem profesyonel futbolcuların hem de amatör futbolcuların öğrenim düzeyleri arttıkça antrenörle iletişimlerinin arttığını belirlemiştir. Gülşen (2008) yılında profesyonel futbolcular üzerinde yapmış olduğu çalışmada üniversite mezunu futbolcuların problem çözme becerileri ile lise mezunu futbolcuların problem çözme beceri ortalamaları; ilköğretim mezunu futbolcuların ortalamalarından daha iyi düzeyde çıkarak aralarında istatistiksel açıdan anlamlı bir farklılığa rastlandığını belirtmiştir. Çalışkur (2008) tarafından üniversite öğrencileri üzerinde yapılan araştırmada bireylerin eğitim durumunun farklılaşmasının da bireylerin değerleri üzerinde etkin bir değişken olduğunu vurgulanmıştır. Adiloğulları (2011) futbolculara yönelik yaptığı çalışmanın bulgularında mezun olunan okul seviyesi arttıkça; kişisel farkındalık, şartlara ve çevreye uyum, stres yönetimi, genel ruh hali, kişiler arası ilişkilerinde artıığına yer vermiştir. Çalışmamızda eğitim seviyesi artıkça futbolcuların kendi gelişimleri için; eğitmenlerden, antrenörlerden, spor hekimlerinden ve idarecilerden destek almasının dolayısıyla dışsal etkiyi kabul etmesinin ve öz yabancılaşma tutumunu esnetmesinin olası olacağı düşünülmektedir. Araştırmada elde edilen sonuçlara göre futbolcuların sporda insan hakları tutumu ve özgünlük düzeylerinin Yaş, Spor Yaşı, Oynadığı Lig ve Eğitim durumuna göre farklılaştı̆̆ tespit edilmiştir. Bu değişkenler göz önünde bulundurularak insan hakları konusunda; topluma öncülük eden, her zaman ön plandaki futbolcuların daha duyarlı hale getirilmesi sağlanabilir.

\section{Öneriler}

- Futbolcuları her yönüyle tanıma ve geliştirmeye yönelik psikolojik unsurların da dikkate alınmasının önemini unutmamalıdırlar.

- Takımdan daha yüksek başarı bekleyen antrenör ve idareciler futbolcuların sadece fiziksel özelliklerine değil aynı zamanda duyuşsal ve bilişsel özelliklerine ve evrensel değerlere yönelik becerilerini geliştirmelidirler.

- Tüm sporculara her şeyden önce iyi bir insan olmanın erdemleri öğretilmelidir. 
- Çalışma sadece profesyonellere değil tüm alt yapıya yapılmalıdır böylelikle erken yaşlarda tedbir alınabilir.

\section{Kaynaklar}

Abakay, U. (2010). Futbolda Antrenör İletişiminin Farklı Statüdeki Futbolcuların Başarı Motivasyonuyla İlişkisi, Yayımlanmamış Doktora Tezi, Gazi Üniversitesi, Ankara.

Adiloğulları, İ. (2011) Profesyonel Futbolcularda Duygusal Zekâ İle Örgütsel Bağlılık İlişkisi, Yayınlanmamış Doktora Tezi Sağlık Bilimleri Enstitüsü, Marmara Üniversitesi.

Akın, A. ve Dönmezoğulları, C. (2010). The Validity And Reliability Of Turkish Versio Of The Authenticity Scale. 2nd International Congress Of Educational Research, 29 April-2 May, Antalya, Turkey.

Avolio, B. J. ve Gardner, W. (2005). Authentic Leadership Development: Getting To The Root Of Positive Forms Of Leadership. The Leadership Quarterly, 16, 315338.

Bilir, P. (2014). Beden Eğitimi Ve Spor Yüksekokulu Öğrencilerinin Şiddet Eğilim Tutumlarının İncelenmesi. Beden Eğitimi Ve Spor Bilimleri Dergisi, 8(1), 73-82.

Bilge, F. (1990). Sporcuların Psikolojik İhtiyaçları. Yayımlanmamış Yüksek Lisans Tezi, Ankara: Hacettepe Üniversitesi Sosyal Bilimler Enstitüsü.

Çalışkur, E. A. (2008). Üniversite Öğrencilerinin Yaşam Değerleri İle Kişilik Özellikleri Arasındaki İlişki. Yayımlanmamış Doktora Tezi. Marmara Üniversitesi Eğitim Bilimleri Enstitüsü. İstanbul.

Çon, M. (2011). Takım Ve Ferdi Sporcuların Kişilik Özellikleriyle Sportif Performansları Arasındaki İlişkinin İncelenmesi. Yayımlanmamış Doktora Tezi, Samsun: On Dokuz Mayıs Üniversitesi Sağlık Bilimleri Enstitüsü.

Coşkun, V. (2006). İnsan Hakları, Liberal Açıdan Bir Tahlil. Ankara: Liberte Yayınları. Erdoğan, B. S. (2014) Profesyonel Futbolcularda Bireysel Değerler Üzerine Bir Araştırma, Yayımlanmamış Doktora Tezi, Eğitim Bilimleri Enstitüsü, Gazi Üniversitesi.

Ersan, E. E. Doğan, O. ve Doğan, S. (2009). Beden Eğitimi Ve Antrenörlük Bölümü Öğrencilerinde Benlik Saygısı Düzeyi Ve Bazı Sosyo demografik Özelliklerle İlişkisi. Klinik Psikiyatri, 12(1), 35-42. 
Göze, A. (2005). Liberal Marxiste Fasist Nasyonal Sosyalist Ve Sosyal Devlet. İstanbul: Beta Yayınları.

Gülşen, D. (2008) Farklı Lig Düzeyinde Oynayan Futbolcuların Oynadıkları Mevkilere, Öğrenim Durumu Ve Spor Yaşlarına Göre Problem Çözme Becerilerinin İncelenmesi, Yayınlanmamış Yüksek Lisans Tezi, Çukurova Üniversitesi Sağlık Bilimleri Enstitüsü, Beden Eğitimi Ve Spor Anabilim Dalı.

İnce, G. Şen, C. (2006). Adana İli'nde Deplasmanlı Ligde Basketbol Oynayan Sporcuların Problem Çözme Becerilerinin Belirlenmesi, Spor metre Beden Eğitimi Ve Spor Bilimleri Dergisi,4(1).

Karasar N. Bilimsel Araştırma Yöntemi (2007) (17.Baskı), Ankara, Nobel Yayın Dağıtım, 49-53.

Kernis, M. H. And Goldman, B. M. (2006). A Multicomponent Conceptualization Of Authenticity: Theory And Research. Advances İn Experimental Social Psychology, 38, 283- 357.

Kirkcaldy, B. D. (1982). Personality Profiles At Various Levels Of Athletic Participation. Personality And Individual Differences, 3, 321-326.

Koruç, Z. Bayar, P. (1990) MMPI Sporcuların Kişiliklerinin Araştırılması Spor Bilimleri Bülteni. (1).2.21-25.

Lopez, F. G. And Rice, G. K. (2006). Preliminary Development And Validation Of A Measure Of Relationship Authenticity. Journal Of Counseling Psychology, 53(3), 362-371.

Nia, M. E. Ve Besharat, M. A. (2010). Comparison Of Athletes' Personality Characteristics İn İndividual And Team Sports. Procedia Social And Behavioral Sciences, 5, 808-812.

Olgun, N. Öntürk, ZK. Karabacak, Ü. Aslan, FE. Serbest, G. (2010). Hemşirelik Öğrencilerinin Problem Çözme Becerileri: Bir Yıllık İzlem Sonuçları. Acıbadem Üniversitesi Sağlık Bilimleri Dergisi,1(4).

Raths, L. E. Harmin, M. and Simon, S. B. (1978). Values And Teaching. Columbus, $\mathrm{OH}$ : Merrill.

Sadık, R. (2014) Sporcularda İnsan Haklarına İlişkin Tutumların İncelenmesi, Yayınlanmamış Yüksek Lisans Tezi, Sosyal Bilimler Enstitüsü, Abant İzzet Baysal Üniversitesi. 
Sağlam, A. (2012). Çalışanların Ve Yöneticilerin Sosyal İstenirlik ve Özgünlük Düzeylerinin Karşılaştırılması. Yayımlanmamış Yüksek Lisans Tezi, Maltepe Üniversitesi, İstanbul.

Salar, B. Hekim, M. Ve Tokgöz, M. (2012). 15-18 Yaş Grubu Takım Ve Ferdi Spor Yapan Bireylerin Duygusal Durumlarının Karşılaştırılması. Mehmet Akif Ersoy Üniversitesi Sosyal Bilimler Enstitüsü Dergisi, 4(6), 123-135.

Tekin, M. (2009). Ferdi Ve Takım Sporlarında Erkek Ve Kız Sporcuların Farkı Zekâ Tiplerindeki Seviyelerinin Karşılaştırılması. Beden Eğitimi Ve Spor Bilimleri Dergisi, 11(4). 29-51.

Wood, A. M. Linley, P. A. Maltby, J. Baliousis, M, Ve Joseph, S. (2008). The Authentic Personality: A Theoretical And Empirical Conceptualization, And The Development Of The Authenticity Scale. Journal Of Counseling Psychology, 55(3), 385-399. 